\title{
地震動強さと継続時間の同時確率密度関数を用いた 地震動の表現とその応用 \\ JOINT PDF OF GROUND MOTION INTENSITY AND DURATION TIME, AND ITS APPLICATIONS
}

\author{
高田毅士*，大㴊 正博** \\ Tsuyoshi TAKADA and Masahiro OOBUCHI
}

\begin{abstract}
In this study, for more detailed probabilistic evaluation of the future ground motions, a method of bivariate probabilistic seismic hazard analysis which evaluates PGV and the duration time simultaneously is proposed through analyses of dense strong motion records in Japan. This method is applied to the hazard analyses at some sites. The results are compared and discussed. For application of this result, this paper proposes a method that calculates conditional probability density function and mean value of the duration time based on the return period of PGV. It is concluded that the method makes it possible to estimate the probabilistic characteristics of the future ground motions in more detail and has wide application.
\end{abstract}

Keywords: Probabilistic seismic hazard assessment, ground motion intensity, duration time, design ground motions, ground motion attenuation law, duration time prediction law 確率論的ハザード評価、地震動強度、継続時間、設計用地震動、地震動距離減衰式、継続時間推定式

1.はじめに

現在行われている確率論的地震動評価においては、地震動の大きさ の指標として最大加速度(PGA)、最大速度(PGV)、計測震度などの地 震動強さに関する指標を用いることが一般的である。しかし、地震動 を表現するには、(1)地震動振幅 (2)周波数特性 (3)経時特性を地震動の 三要素として表現することが重要である ${ }^{1)}$ 。建築物に入力される地震 動のエネルギーは地震動の強度特性だけでなく、経時特性とも密接な 関倸をもつことから 2$) 、$ 特に構造物が破壊に至るような非線形応答の 領域において経時特性は重要な指標のひとつである3)。この点におい て、地震動を最大振幅といったスカラー量のみで表現する確率論的地 震動評価は、不十分と言わざるを得ない。

一方、現在、動的設計を行なう超高層建物、原子力施設等において は、実地震記録を用いる以外に設計用态答スペクトルに適合する模擬 地震動を作成して、それを設計用地震動として用いることが一般的で ある。模擬地震動作成手法は過去に色々提案されているが4),5,6) 、上 述した地震動の三要素が相互に整合が取れている必要がある。すなわ ち、これらの三要素は密接に関連があり、それぞれ無関係に性格づけ られるものではない。最近の震源特性、伝播特性を反映した地震動評
価研究によれば、地震動の周波数特性と震源特性、伝播特性の関連7), 8) 経時特性と震源特性、伝播特性の関連性が指摘されている。 周波数特性や経時特性は地震を特定することによって決定するこ とができる。例えば亀田・石川 6)ではハザード曲線での指定超過確率 における地震のマグニチュードと震央距離を特定することによって 周波数特性や経時特性の地震動パラメ夕を評価する手法を提案して いる 9)。高田ら 10)はさらに距離減衰式の不確定性を考慮して地震のマ グニチュードと震央距離を特定している。しかしながら、これらの手 法では地震動強さを PGV のみでしか議論していない。PGV が大き ければ建物の応答も大きくなるのは事実であるが、建物の応答は建物 の周期特性、非線形応答の特性にも依存する。すなわち、地震動を表 現するのに、PGV, 周波数特性、経時特性を考慮に入れて地震を特定 する必要がある。

そこで本研究では、地震動を表す指標として地震動強さだけではな く、経時特性のうち地震動の継続時間を同時に評価した確率論的地震 動評価手法を提案する。手法構築にあたっては、複数のハザード指標 を同時に評価する際、ある震源によってもたらされる指標の同時確率 密度関数を適切に評価する必要がある。そこで、KiK-net と K-net の

* 東京大学大学院工学系研究科建築学専攻 教授. 工博

** 東京大学大学院工学系研究科建築学専攻 修士課程 
多地点強震観測記録を用いて、それぞれの指標の予測式に関する検討 を行い、さらに、推定式が持つ不確定性と、指標同士の相関性に関す る評価を行う。

次にこの結果を用いて、地震動強さと継続時間に関する指標を同時 に評価する確率論的地震八ザード解析の手法を提案し、具体的な複数 の地点における地震八ザードを評価し、考察を加えるとともに、地震 動強さと継続時間の同時確率密度関数の設計用地震動への応用方法 についても報告する。すなわち超過確率あるいは設計用再現期間を指 定した時の時刻歷波形の策定方法への応用である。

\section{PGV や継続時間の評価}

\section{1. 解析に用いた観測記録}

ある震源によってもたらされる、地震動強さと継続時間に関する同 時確率密度関数を評価するため、K-NET および KiK-net の多地点強震 観測記録を用いた解析を行った。解析に用いた地震は、ある程度マグ ニチュードが大きく、かつ高密度に観測された最近の地震を選んだ。 それらを表1に示す。表1ではスラブ内地震の割合が多くなっており、 以下の結果は、この影響が少なくない事を明記しておく。

地表面で得られた加速度波形に $0.2 \sim 10 \mathrm{~Hz}$ のバンドパスフィルター をかけたものを解析に用いた。また、PGVの距灕减衰特性について

表 1 解析に用いた観測記録

\begin{tabular}{|c|c|c|c|c|}
\hline No & 日時 & 厝源 & $M w$ & 断層タイブ \\
\hline 1 & $1999 / 8 / 21$ & 和歌山県北部 & 5.6 & スラブ内 \\
\hline 2 & $2000 / 6 / 3$ & 千葉県北東部 & 6.1 & プレ一ト境界 \\
\hline 3 & $2000 / 7 / 21$ & 茨城沖 & 6.0 & プレート境界 \\
\hline 4 & $2000 / 10 / 6$ & 鳥取県西部 & 6.6 & 地壳内 \\
\hline 5 & $2000 / 10 / 31$ & 三重県中部 & 5.5 & スラブ内 \\
\hline 6 & $2001 / 3 / 24$ & 芸予 & 6.8 & スラブ內 \\
\hline 7 & $2001 / 4 / 25$ & 日向灘 & 5.7 & スラブ内 \\
\hline 8 & $2001 / 4 / 27$ & 根室半島南東沖 & 6.0 & スラブ内 \\
\hline 9 & $2001 / 12 / 2$ & 岩手県内陸南部 & 6.5 & スラブ内 \\
\hline 10 & $2002 / 11 / 3$ & 宮城県沖 & 6.4 & プレート境界 \\
\hline 11 & $2002 / 11 / 4$ & 日向灘 & 5.7 & スラブ内 \\
\hline 12 & $2003 / 5 / 26$ & 宫城県沖 & 7.0 & スラブ内 \\
\hline 13 & $2003 / 7 / 26$ & 宮城県北部 & 6.2 & 地壳内 \\
\hline 14 & $2003 / 9 / 26$ & 十勝沖 & 8.0 & プレート境界 \\
\hline
\end{tabular}

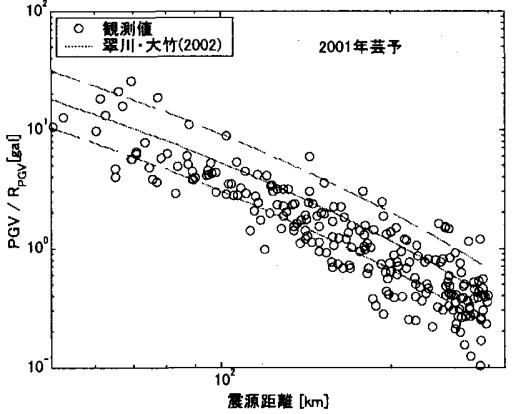

図 1 最大速度の観測値と推定式の関係 (2001 年芸予地震)

は翠川・大竹の式》を用いることを前提に観測地盤の $\mathrm{S}$ 波速度のデー 夕を用いて、観測点ごとに梁さ $30 \mathrm{~m}$ までの平均 $\mathrm{S}$ 波速度 $A V S_{30}$ を求 めた。

\section{2. 地震動強さの推定式}

地震動強さの指標としては最大速度（PGV）を用い、推定式として は翠川・大竹》による工学的基盤における最大速度の推定式を用いた。 工学的基盤と地表面の間の変換には、松岡・翠川辛による、 $A V S_{30}$ と地 盤増幅度の関係式を用いた。2001年芸予地震の記録と推定式との比較 を図1に示寸。縦軸は地震記録を地盤增幅度 $R_{P G V}$ で除し、工学基盤上 の地震動速度に変換している。平均的な值にはややずれが見られるも のの、距稚依存性については観測值と推定式がよく適合している。

\section{3. 経時特性の指標と推定式}

経時特性の指標としては、位相特性・ランニングスペクトル等があ るが、ここでは継続時間を用いた。ただし継続時間には様々な定義が あり、それぞれについて推定式が提案されていることから、表2に示 した継続時間の定義および推定式について用いるべき式を選定する ために表1の全ての地震に対して比較を行った。その一例として、2001 年芸予地震の観測記録について比較した結果を図2に示す。

継続時間は震源距離に対して明確な依存性を持っているため、距離 依存性を持たない太田ら ${ }^{11)}$ の推定式を用いることは適当ではないと 考えられる。Bolt の定義を用いた川島ら ${ }^{12)}$ の推定式、および $\mathrm{p}$ 継続時 間に関寸る沢田ら ${ }^{13)}$ の推定式は、距離依存性をもつものの、観測值に 対して距離依存性が適合しない。g 継続時間を用いた沢田ら ${ }^{13)}$ の推定 式は、平均的な值はややずれているものの、距離依存性については比 較的よく適合しており、ばらつきが小さいという特徴が見られる。し かし、 $\mathrm{g}$ 継続時間は、地震波の短周期成分によってほぼ決まってしま い、長周期成分を多く含む表面波の影響は少ない。表面波が地盤条件 の影響を大きく受けるため、 $\mathrm{g}$ 継続時間は地盤による継続時間の伸長

表 2 本研究で比較した継続時間の定義と推定式

\begin{tabular}{|c|c|c|c|c|c|c|}
\hline & 種類 & \multicolumn{2}{|c|}{ Bolt の定義 } & $\begin{array}{l}\text { Trifunac and Brady } の \\
\text { 定義（p 継続時間） }\end{array}$ & $\begin{array}{l}\left.\text { 沢田ら }{ }^{13}\right) \text { の定義 } \\
(\mathrm{g} \text { 継続時間 })\end{array}$ & 佐藤ら ${ }^{14)}$ の定義 \\
\hline \multicolumn{2}{|r|}{ 定義 } & \multicolumn{2}{|c|}{$\begin{array}{c}\text { 地震波の振幅があるレベルを } \\
\text { 最初に超える時刻から } \\
\text { 最後に超える時刻までの時間 }\end{array}$} & $\begin{array}{c}\text { 地震動の累積パワーが } \\
\text { 全パワーの5\%に達する } \\
\text { 時刻から95\%に達する } \\
\text { 時刻までの時間 }\end{array}$ & $\begin{array}{c}\text { 群遅れ時間の } \\
\text { 標準偏差 }\end{array}$ & $\begin{array}{c}\text { Jennings型包絡形におい } \\
\text { て最大振幅の } 1 / 10 \text { になる } \\
\text { までの時間 }\end{array}$ \\
\hline \multirow{3}{*}{$\begin{array}{l}\text { 推 } \\
\text { 定 } \\
\text { 式 }\end{array}$} & 種類 & 太田ら"11) (久田式) & 川島ら12) & 沢田 13) $^{13)}$ & 沢田ら ${ }^{13)}$ & 鎌田ら ${ }^{3)}$ \\
\hline & $\begin{array}{c}\text { パラメ } \\
\text { ータ }\end{array}$ & 気象庁マグニチュード & $\begin{array}{c}\text { 気象庁マグニチュード } \\
\text { 震央距離 }\end{array}$ & $\begin{array}{c}\text { 気象庁マグニチュード } \\
\text { 震央距離 }\end{array}$ & $\begin{array}{c}\text { 気象庁マグニチュード } \\
\text { 震央距離 }\end{array}$ & $\begin{array}{c}\text { 気象庁マグニチュード } \\
\text { 震源距離 }\end{array}$ \\
\hline & 記録 & $\begin{array}{c}\text { 国立防災科学技術 } \\
\text { センター } \\
\text { (1968年〜1973年) }\end{array}$ & $\begin{array}{c}\text { 運輸省港湾技術研究所 } \\
\text { 建設省土木研究所 } \\
\text { (1963年～1980年 })\end{array}$ & $\begin{array}{c}\text { 運輸省港湾技術研究所 } \\
\text { 建設省土木研究所 } \\
\text { (1962年～1978年) }\end{array}$ & $\begin{array}{l}\text { 運輸省港湾技術研究所 } \\
\text { 建設省土木研究所 } \\
(1962 \text { 年 1978年) }\end{array}$ & $\begin{array}{c}\mathrm{K} \cdot \mathrm{NET} \\
\mathrm{KiK} \cdot \mathrm{net} \\
(1998 \text { 年 } \sim 2003 \text { 年 })\end{array}$ \\
\hline
\end{tabular}



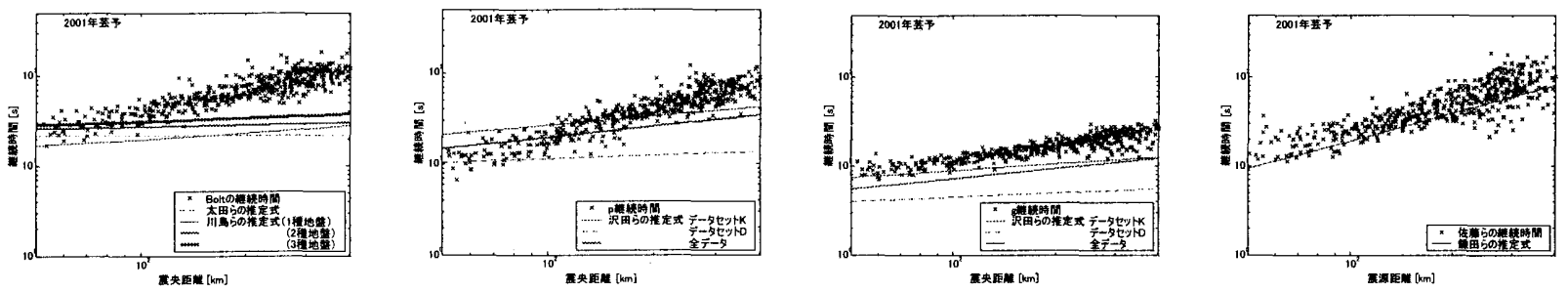

図 2 継続時間の定義の比較 (2001 年芸予地震)

効果を受けにくいという性質がある。地震八ザード解析を行うにあた っては地盤条件の影響を無視することはできないため、このような性 質をもつことはむしろ八ザードの指標として望ましくない。佐藤ら ${ }^{14)}$ の定義を用いた鎌田ら ${ }^{3)}$ の推定式は、観測值とおおむおねよく対応して おり、距離依存性についてもよく適合している。この理由として、i) 鎌田らの推定式は本研究でも用いている KiK-netの観測記録を用いて 作成されたものであり、データセットの違いや地震計の特性等の違い に起因する差異が小さいこと、ii）他の推定式と違い、震源からの距 離として震央距離ではなく震源距離を用いており、震源の深さが考慮 されていること、などが挙げられる。また、佐藤らの継続時間は Jennings 型の包絡形 ${ }^{14)}$ と対応することから、地震波の経時特性との対 态が比較的明確であるという利点もある。上述の傾向は他の地震でも 同様に見られることがわかった。

以上の結果から、本研究では、継続時間の定義として佐藤らの定義 を、継続時間の推定式として鎌田らの式を用いることとした。

\section{4． 継続時間の地盤条件による影響}

鎌田らの推定式は工学的基盤における地震動の継続時間の推定式 であるから、地表面の地震動の継続時間を評価するには継続時間の伸 長度 $R_{T_{d}}$ を評価しなければならない。そこで $R_{T_{d}}$ が式(1)によって表さ れるとして、全ての地震の観測記録を用いて回帰を行い、 $\alpha=0.177$ と推定した。

$$
\ln \left(R_{\left.T_{d}\right)}=\alpha\left[\ln \left(A V S_{30}\right)-\ln (600)\right]\right.
$$

\section{3. 地震動強さと継続時間のばらつきと相関性}

3.1. 同時評価モデル

ある震源による、最大速度と継続時間の同時確率密度関数を評価寸 るため、最大速度の観測值 $V$ と継続時間の観測值 $T_{d}$ を式(2)および式

(3)のようにモデル化する。

表 3 ハザ一ド解析の手法の概要

\begin{tabular}{|c|c|c|c|c|c|}
\hline \multicolumn{3}{|c|}{ 震源タイプ } & 活断層 & プレート境界地震 & $\begin{array}{l}\text { ランダム地震 } \\
\text { (活動域) }\end{array}$ \\
\hline \multicolumn{3}{|c|}{ 震源データ } & $\begin{array}{c}\text { 松田らの起震断層を } \\
\text { ベースに修正 }\end{array}$ & $\begin{array}{l}\text { 宮城県沖、南海、 } \\
\text { 東南海、東海、関東 }\end{array}$ & $\begin{array}{c}\text { 松田らの地体構造区分 } \\
\text { プレート境界を考慮 }\end{array}$ \\
\hline \multicolumn{3}{|c|}{ 規模と発生頻度 } & \multicolumn{2}{|c|}{ 震源ごとに固有のマグニチュードと平均活動間隔 } & $\begin{array}{c}\text { Gutenberg-Richter 式 } \\
(b \text { 值モデル })\end{array}$ \\
\hline \multicolumn{3}{|c|}{ 地震発生過程 } & $\begin{array}{c}\text { 最新活動時期からの } \\
\text { 経過時間を考屡するモデル } \\
\text { or 定常ポアソン過程 } \\
\end{array}$ & $\begin{array}{c}\text { 最新活動時期からの } \\
\text { 経過時間を考橿するモデル }\end{array}$ & 定常ポアソン過程 \\
\hline \multirow{4}{*}{$\begin{array}{r}\text { 公 } \\
\text { ザ } \\
\text { 预 } \\
\text { 式指 } \\
\text { 標 } \\
\text { の }\end{array}$} & \multirow{2}{*}{$\begin{array}{l}\text { 最大 } \\
\text { 速度 }\end{array}$} & 工学的基盤 & \multicolumn{3}{|c|}{ 翠川・大竹による、断層面最短距離に対する距離減衰式 } \\
\hline & & 地盤増幅度 & \multicolumn{3}{|c|}{ 松岡・翠川による、深さ $30 \mathrm{~m}$ までの平均 $\mathrm{S}$ 波速度に対する推定式 } \\
\hline & \multirow{2}{*}{$\begin{array}{l}\text { 継続 } \\
\text { 時間 }\end{array}$} & 工学的基盤 & \multicolumn{3}{|c|}{ 鎌田らによる、継続時間の推定式 } \\
\hline & & 伸長度 & \multicolumn{3}{|c|}{ 本研究の推定式（1） } \\
\hline
\end{tabular}

$$
\begin{aligned}
& V=V_{m}\left(M_{w}, X\right) \varepsilon_{V_{\text {INTER }}} \cdot \varepsilon_{V_{\text {INTRA }}} \\
& T_{d}=T_{d m}\left(M_{j}, X\right) \varepsilon_{T_{d I N T E R}} \cdot \varepsilon_{T_{d I N T A}}
\end{aligned}
$$

ここに $M_{w}$ はモーメントマグニチュード、 $M_{j}$ は気象庁マグニチュード、 $\mathrm{X}$ は断層面最短距離である。 $V_{m}(M, X)$ および $T_{d m}\left(M_{j}, X\right)$ はそれぞれの 推定式の中央值である。 $\varepsilon_{V_{I N T E R}}$ と $\varepsilon_{T_{d I N T E R}}$ は地震間のばらつき成分、 $\varepsilon_{V_{I N T R A}}$ と $\varepsilon_{T_{d I N T R A}}$ は地震内のばらつき成分であり、各々、中央值が $(1,1)$ の相関を有する2変量の対数正規分布にしたがうとした。それぞれの ばらつきの対数標準偏差と、地震内のばらつきの相関係数および地震 閒のばらつきの相関係数が得られれば、 $V$ と $T_{d}$ の同時確率密度関数 を評価することができる。

\section{2. 地震内のばらつきと相関性}

各地震記録について、観測值の地震内のばらつき $\varepsilon_{V_{I N T R A}}$ および $\varepsilon_{T_{d}}$ INTRA に関する検討を行った。この結果、地震によってばらつきはある ものの、最大速度の対数標準偏差は $0.5 \sim 0.6$ 程度、継続時間の対数標 準偏差は0.3〜0.4程度となった。また、 $\varepsilon_{V_{I N T R A}}$ と $\varepsilon_{T_{d I N T R A}}$ の相関係数は $-0.2 \sim-0.4$ 程度の弱い相関が見られるが、独立として扱うことができ ると考えられる。

\section{3. 地震間のばらつきと相関性}

地震間のばらつき成分 $\varepsilon_{V_{I N T E R}} お よ ひ ゙ \varepsilon_{T_{d I N T E R}}$ に関する検討を行った。 それぞれの地震における対数推定残差の平均値の地震の違いによる ばらつきが地震間のばらつき成分に相当するとした。

統計解析の結果、プレート境界型地震の継続時間の対数推定残差が スラブ内地震に比べて大きい傾向が見られた。スラブ内地震では、発 生した地震動がスラブに沿って伝わることで震源距離の割には継続 時間が伸長しにくいために、プレート境界型地震の継続時間が相対的 に長くなると考えられる。しかし鎌田らの推定式では両者を区別して いないためにこのような傾向が現れたと考えられることから、本研究 ではプレート境界地震の継続時間については、補正係数を乗ずること 


\begin{tabular}{|c|c|}
\hline ○ 1.1999 年和歌山県北部 Mw5.8 & $\Delta 2.2000$ 年千葉県北東部 Mw6.1 \\
\hline$\Delta 3.2003$ 年茨城県沖 Mw6.0 & 。 4. 2000年鳥取県西部 Mw6.6 \\
\hline ○ 5.2000 年三重県中部 Mw5.5 & D01年芸予 \\
\hline ・ 7. 2001年日向灘 Mw5.7 & - 8.2001 年根室半島南東沖 Mw6.0 \\
\hline - 9. 2001年岩手県内陸南部 Mw6.5 & 4 10. 2002年宮城県沖 Mw6.4 \\
\hline 口 11. 2002年日向灘 Mw5.7 & 口 12. 2003年宫城県沖Mw7.0 \\
\hline 口 13. 2003年宮城県北部 Mw6.2 & $\Delta 14.2003$ 年十勝沖 Mw8.0 \\
\hline
\end{tabular}

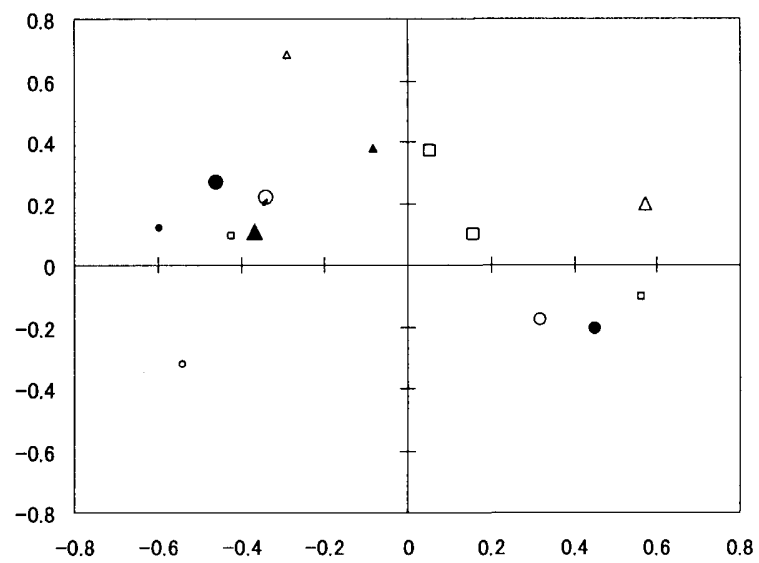

図 3 地震間のばらつき成分どうしの関係

にした。観測記録より、この補正係数は $e^{0.347}=1.41$ と求められた。地 殸内地震については、観測記録と推定式がほぼ対态していたため、補 正は行なっていない。このような補正を行った上で、最大速度および 継続時間に関して、地震間のばらつき成分の関係を図3に示す。地震 間のばらつき成分の対数標準偏差 $\varepsilon_{V_{I N T E R}}$ と $\varepsilon_{r_{d I N T E R}}$ はそれぞれ0.41およ び0.21と得られた。地震間のばらつき成分どうしの相関係数は-0.29 であり、ほぼ独立とみなしてよいと考えられる。これらの考察結果は 対象としたスラブ内地震やプレート境界地震を含むデータからのも のであり、今後はデータ数を増やした検討が必要と考えられる。

\section{4. ハザード解析の結果}

\section{1 手法の概要}

本研究で用いた八ザード解析手法の概要を表3に示す。Cornell の手

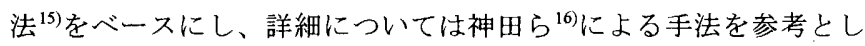
た。本ハザード解析は地震動強さの超過確率を評価する代わりに、最 大速度と継続時間の同時超過確率を評価するところが特徵的である。

最大速度および継続時間の対数標準偏差は、それぞれ0.64および 0.41 と設定し、ばらつきの相関は無視できるとした。

\section{2 評価対象地点}

本研究の手法で地震ハザード解析を行った評価対象地点の 一覧を表4に示した。いずれも K-NET もしくは KiK-net の観 測点である。また、評価期間はすべて 50 年とした。

4.3 継続時間ごと、または最大速度ごとのハザードカーブ

図4に、TKY007においてハザード解析を行った結果を、継続時間ご とあるいは最大速度ごとの八ザードカーブとしてプロットした図を 示す。継続時間が50秒長くなるごとに超過確率が $1 / 10 〜 1 / 5$ 程度に減少 しているのがわかる。
表 4 比較した評価対象地点の一覧

\begin{tabular}{|c|c|c|c|c|c|}
\hline No & 観測点コード & 地名 & 緯度 & 経度 & $A V S_{30}$ \\
\hline 1 & MYGH06 & 宮城県遠田郡田尻町 & $38.5878 \mathrm{~N}$ & $141.0744 \mathrm{E}$ & $\begin{array}{c}593.1 \\
\mathrm{~m} / \mathrm{s}\end{array}$ \\
\hline 2 & TKY007 & 東京都新宿区 & $35.7075 \mathrm{~N}$ & $139.6891 \mathrm{E}$ & $\begin{array}{c}283.7 \\
\mathrm{~m} / \mathrm{s}\end{array}$ \\
\hline 3 & SZO014 & 静岡県静岡市 & $34.9616 \mathrm{~N}$ & $138.3766 \mathrm{E}$ & $\begin{array}{c}370.4 \\
\mathrm{~m} / \mathrm{s}\end{array}$ \\
\hline 4 & $\mathrm{AIC015}$ & 愛知県豊橋市 & $34.7516 \mathrm{~N}$ & $137.4077 \mathrm{E}$ & $\begin{array}{c}340.0 \\
\mathrm{~m} / \mathrm{s}\end{array}$ \\
\hline 5 & OSK005 & 大阪府大阪市 & $34.7222 \mathrm{~N}$ & $135.5127 \mathrm{E}$ & $\begin{array}{c}250.0 \\
\mathrm{~m} / \mathrm{s}\end{array}$ \\
\hline 6 & FKOH01 & 福岡県北九州市 & $33.8817 \mathrm{~N}$ & $130.9822 \mathrm{E}$ & $\begin{array}{c}588.5 \\
\mathrm{~m} / \mathrm{s}\end{array}$ \\
\hline
\end{tabular}

このように、最大速度と継続時間は両者関連があり、本研究で提案 するハザード解析を用いれば最大速度と継続時間に関するハザード 曲面（同時超過確率等）を評価することができる。

\section{4 確率密度関数の比較}

図5には対象とする6地点の同時確率密度関数をモデル化した震源 タイプ（活断層、プレート境界、ランダム地震域、全震源タイプを考 慮）毎にコンター図で示した。これらの図より、以下の点が読み取れ る。

(a)活断層によるハザードは、MYGH06と FKOH01では50年超過確 率10\%の最大速度が5〜10kine と小さいのに対し、SZO014と AIC015 では20 40kine と比較的大きい。前者は評価対象地点近傍に設定され た活断層がないのに対し、後者は比較的近傍に活断層があり、地域性 の違いが明確に見られる。

(b)プレート境界地震によるハザードは、評価対象地点ごとの地域 性が極めて明瞭である。SZO014及び AIC015においては、大きく性質

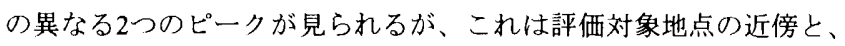

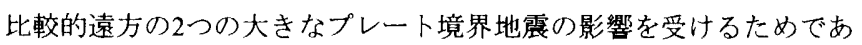
る。

(c)ランダム地震域によるハザードは、活断層やプレート境界地震 の場合とは対照的に、明瞭な地域性は見られない。

このように、最大速度と継続時間を同時に評価した地震八ザード解 析により、最大速度と継続時間の同時生起確率という視点から、評価 対象地点周辺の震源分布の特徴や、それによってもたらされる地震動 の特徴を明らかにすることができる。

\section{5. 同時確率密度関数を用いた設計用地震動設定方法}

性能に基づく耐震設計で用いる設計用地震動設定の考え方と策定 方法は重要な課題であり、いろいろな提案がなされている ${ }^{4), 5), 6)}$ 。し かしながら既往の手法では地震動の三要素の内地震動強度特性に重 点を置いて解析しているものがほとんどであり、継続時間を考慮に入 れているものは少ない。本研究では先に評価された継続時間と地震動 強度の同時確率密度関数を用いて設計用再現期間に対応する地震動 策定方法のひとつについて紹介する。

\section{1. 性能設計対応設計用地震動}

建物の性能設計においては、建物の目標性能（安全性、修復性、使 用性）に対応した時刻歷波形を作成する必要がある。また、設計用地 震動の大きさは、再現期間を定めて規定することが多い。この際、地 震動時刻歴波形を定義するには、地震動の PGA, PGV 等の地震動強 


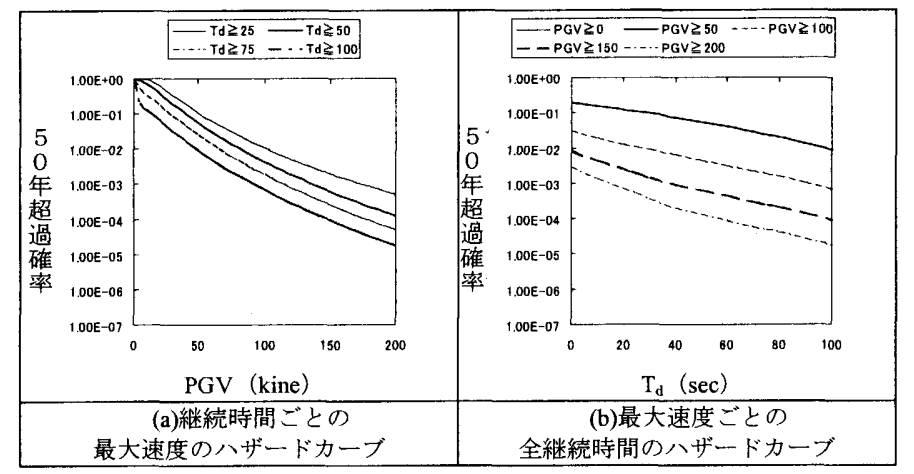

度のみならず、スペクトル特性、経時特性を定める必要がある。ここ では、従来にならって、地震動強度に関して指定された超過確率（再 現期間）を条件として継続時間を定める方法について述べる。すなわ ち、地震動強度と継続時間の同時確率密度関数を用いて、地震動強度 の周辺分布関数（従来の地震強度によるハザード曲線）に対して再現 期間を規定し、継続時間に関する条件付確率密度関数から継続時間の 代表值を定める方法である。

そして、一旦地震動強度、継続時間が確定できればそれに周波数特 性を考慮することによって、時刻歷波形を作成することができる。

図 4 継続時間ごと、または最大速度ごとのハザードカーブ (TKY007)

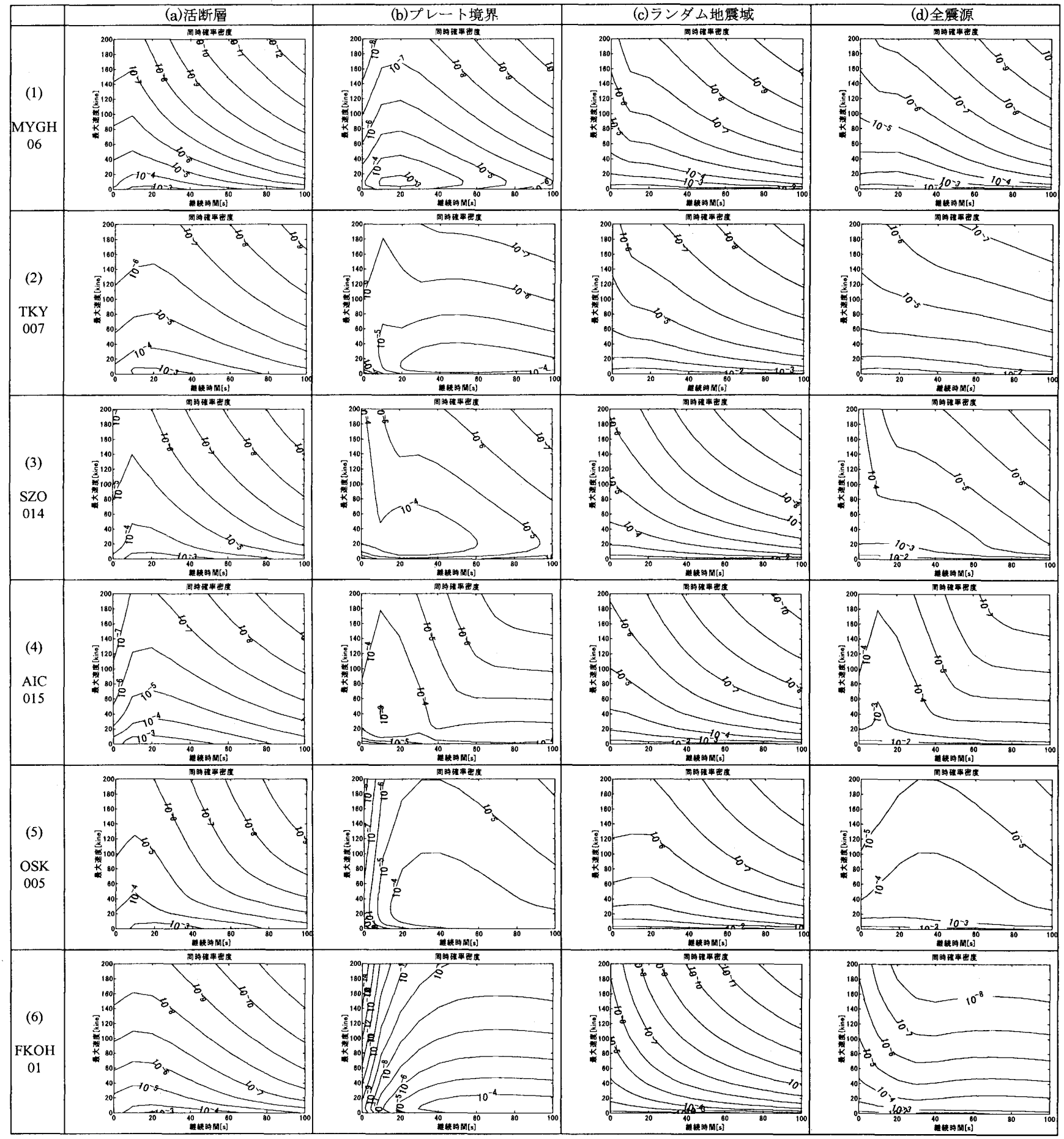

図 5 評価地点ごとの最大速度と継続時間のハザードの確率密度関数（評価期間 50 年） 
以下では、本来周波数特性も指定した再現期間によって変化するは ずであるが、この影響については今後の課題とし、周波数特性を固定 した応答スペクトルの形状で仮に与えることにした。

評価期間 50 年に対し、地震動強度 $V$ 、継続時間を $T_{d}$ とすると、こ れらの同時累積分布関数 $F_{V T_{d}}\left(v, t_{d}\right)$ は次式で与えられる。

$$
F_{V T_{d}}\left(v, t_{d}\right)=\operatorname{prob}\left[V<v \text { and } T_{d}<t_{d}\right]
$$

上式より、最大地動速度 $V$ のみの従来の評価期間 50 年のハザード 曲線は、

$$
1-F_{V}(v)=1-F_{V T_{d}}(v,+\infty)=P_{50}
$$

となり、 $V$ に関する超過確率 $P_{50}$ を下のベルヌーイの仮定を用いて、 1 年の超過確率 $P$, にすると

$$
P_{1}=1-\left(1-P_{50}\right)^{\frac{1}{50}}
$$

その逆数 $1 / P_{1}=n$ が再現期間 $n$ 年に対応寸ることになる。これらよ り、地動最大速度に関して再現期間 $n$ が与えられた条件の下での継続 時間に関する条件付確率密度関数 $f_{T_{d} V}\left(t_{d} \mid V \geq v_{n}\right)$ あるいは条件付 累積分布関数 $F_{T_{d} \mid V}\left(t_{d} \mid V \geq v_{n}\right)$ を求めてみる。

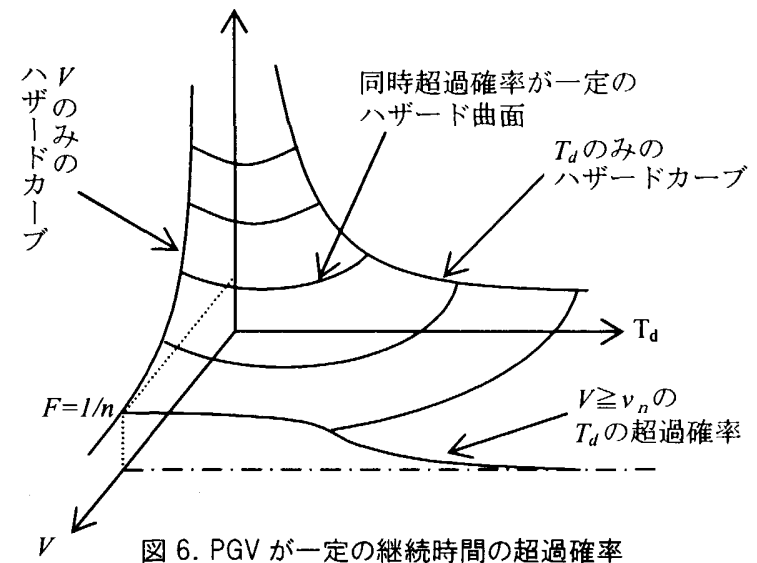

ハザード解析によって図 6 のような 50 年同時超過確率分布が得ら れ、これから 50 年同時累積分布関数 $F_{V T_{d}}\left(v, t_{d}\right) 、 50$ 年同時確率密度 $f_{V T_{d}}\left(v, t_{d}\right)$ が計算できる。そして, 継続時間の条件付確率密度関数 $f_{T_{d} \mid V}\left(t_{d} \mid V \geq v_{n}\right)$ を以下のように算出する。

$$
\int_{0}^{t_{d}} f_{T_{d} \mid V}\left(t_{d} \mid V \geq v_{n}\right) d t_{d}=F_{T_{d} \mid V}\left(t_{d} \mid V \geq v_{n}\right)
$$

ここで $F_{T_{d} \mid V}\left(t_{d} \mid V \geq v_{n}\right)$ は、 $V \geq v_{n}$ の条件下で $T_{d}$ が $t_{d}$ 以下である確率 であるから、

$$
F_{T_{d} \mid V}\left(t_{d} \mid V \geq v_{n}\right)=\operatorname{prob}\left(T_{d}<t_{d} \mid V \geq v_{n}\right)
$$

ここで $\operatorname{prob}\left(T_{d}<t_{d} \mid V \geq v_{n}\right)$ は、条件付確率の式より $\operatorname{prob}\left(V \geq v_{n}\right) \operatorname{prob}\left(T_{d}<t_{d} \mid V \geq v_{n}\right)$

$$
=\operatorname{prob}\left(T_{d}<t_{d} \text { and } V \geq v_{n}\right)
$$

$\operatorname{prob}\left(V \geq v_{n}\right)=\int_{0}^{\infty} \int_{v_{n}}^{\infty} f_{V T_{d}}\left(v, t_{d}\right) d v d t_{d}=P_{50}$

であり、また式(1)の右辺は

$\operatorname{prob}\left(T_{d}<t_{d}\right.$ and $\left.V \geq v_{n}\right)=\int_{v_{n}}^{\infty} \int_{0}^{t_{d}} f_{V T_{d}}\left(v, t_{d}\right) d t_{d} d v$ $=\int_{v_{n}}^{\infty}\left[\int_{0}^{\infty} f_{V T_{d}}\left(v, t_{d}\right) d t_{d}-\int_{0}^{t_{d}} f_{V T_{d}}\left(v, t_{d}\right) d t_{d}\right] d v$

$=\int_{v_{n}}^{\infty} \int_{0}^{\infty} f_{V T_{d}}\left(v, t_{d}\right) d t_{d} d v-\int_{v_{n}}^{\infty} \int_{t_{d}}^{\infty} f_{V T_{d}}\left(v, t_{d}\right) d t_{d} d v$

$=P_{50}-\operatorname{prob}\left(V \geq v_{n}\right.$ and $\left.T_{d} \geq t_{d}\right)$

ここで、 $n$ 年再現期間において

$$
P_{50}=1-\left(1-\frac{1}{n}\right)^{50}
$$

$\operatorname{prob}\left(V \geq v_{n}\right.$ and $\left.T_{d} \geq t_{d}\right)$ は同時超過確率であり、これが先のハザ 一ド曲面によって与えられている。従って、

$P_{50} F_{T_{d} \mid V}\left(t_{d} \mid V \geq v_{n}\right)=P_{50}-\operatorname{Prob}\left(V \geq v_{n}\right.$ and $\left.T_{d} \geq t_{d}\right)$

$F_{T_{d} \mid V}\left(t_{d} \mid V \geq v_{n}\right)=1-\frac{\operatorname{Prob}\left(V \geq v_{n} \text { and } T_{d} \geq t_{d}\right)}{P_{50}}$

$f_{T_{d} \mid V}\left(t_{d} \mid V \geq v_{n}\right)=\frac{\partial\left(1-\frac{\operatorname{Prob}\left(V \geq v_{n} \text { and } T_{d} \geq t_{d}\right)}{P_{s_{0}}}\right)}{\partial t_{d}}$

ここで、 $\widetilde{F}_{V T_{d}}\left(v_{n}, t_{d}\right)=\operatorname{Prob}\left(V \geq v_{n}\right.$ and $\left.T_{d} \geq t_{d}\right)$ であるから

$$
f_{r_{d} \mid V}\left(t_{d} \mid V \geq v_{n}\right)=-\frac{1}{P_{50}} \frac{\partial}{\partial t_{d}}\left[\widetilde{F}_{V T_{d}}\left(v_{n}, t_{d}\right)\right]
$$

また、上で得られた条件付確率密度関数 $f_{T_{d} \mid V}\left(t_{d} \mid V \geq v_{n}\right)$ を用い て継続時間の代表值を算定できる。継続時間の代表值について(よ)平 均值や $90 \%$ 非超過確率、最頻值などが考えられる。本研究では継続 時間を求める際にVの超過確率を決定しているため、継続時間の $90 \%$ 非超過確率など分布の裾野を代表値としてしまうと、評価された地震 動は再現期間が過大となり、著しく安全側に見積もることになる。例 えば $V$ の再現期間が 500 年の時、90\%非超過確率を用いると $500 \times 10$ $=5000$ 年相当の再現期間になる。そのため平均值や最頻値の方が継 続時間の代表値として相応しいといえる。条件付平均継続時間は以下 のように得られる。

$$
\overline{T_{d}}\left(P_{S 0}\right)=E\left[T_{d} \mid V \geq v_{n}\right]=\int_{0}^{\infty} t_{d} f_{T_{d} \mid}\left(t_{d} \mid V \geq v_{n}\right) d t_{d}
$$

\section{2. ハザード解析に基づく地震動のパラメータ}

この解析を、実際にハザード解析を行った 6 地点について行なった。 まず再現期間として、中地震動として再現期間 75 年 $(50$ 年超過確率 で 0.49）の地震動強度 $v_{75}$ と、稀な地震動として再現期間 250 年（50 年超過確率で 0.18）の地震動強度 $v_{250}$ を設定した。それぞれの再現期 間についての継続時間の条件付確率密度 $f_{T_{d} \mid V}\left(t_{d} \mid V=v_{n}\right)$ を算出し、 図 7 に示寸。

図 7 より地震動強度(PGV)の再現期間が同じであっても、地域によ って継続時間の分布は様々になることがわかり、継続時間は地域特性 を考慮して決定しなければならないといえる。例えば、250 年再現期 間において SZO014 は継続時間 10 秒以下の直下型地震による地震動 が支配的であり、対して OSK005 は継続時間 40 秒程度の地震動が支 配的であることがわかる。すなわち、地震動強度の再現期間を決定し、 継続時間を別途決定する従来の手法は、地域特性を考慮していないこ とが問題であったといえる。しかし、本研究の手法を用いれば地震動 

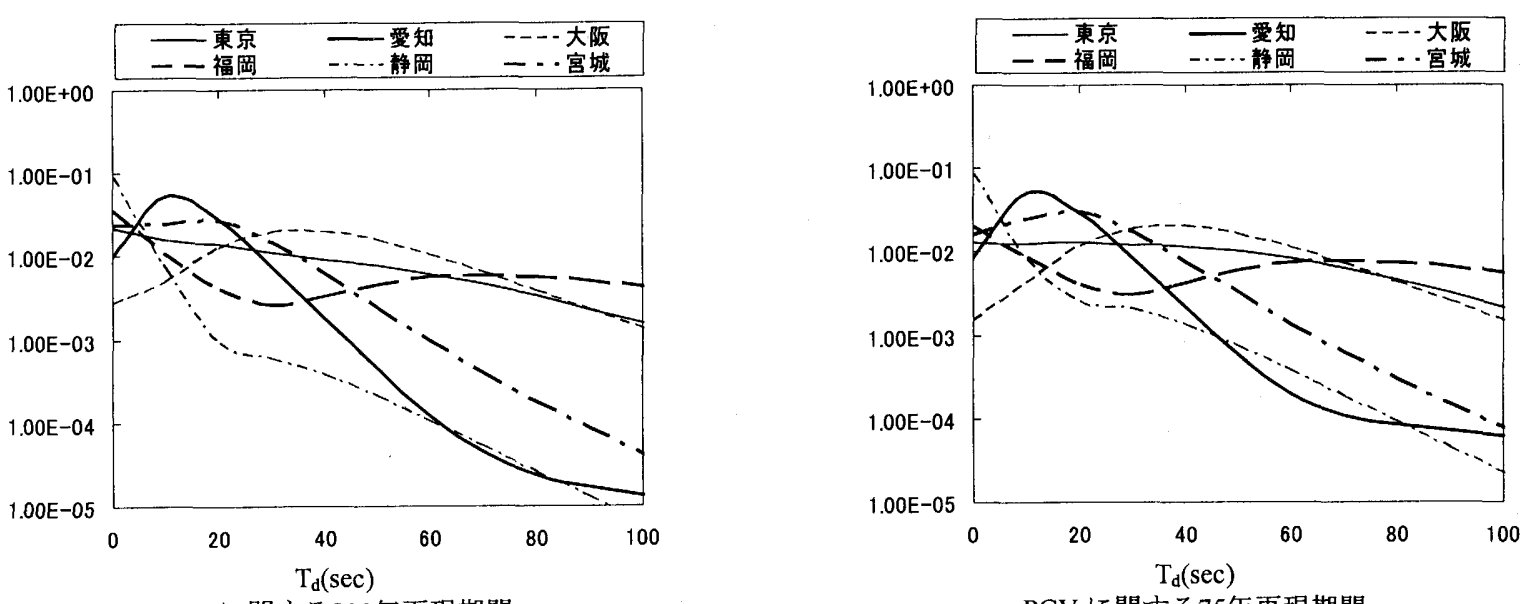

図7. 継続時間と条件付確率密度関数

表5. 250 年再現期間, 75 年再現期間での

PGV の大きさと継続時間の平均値

\begin{tabular}{|c|c|c|c|c|}
\cline { 2 - 5 } \multicolumn{1}{c|}{} & \multicolumn{2}{c|}{$\begin{array}{c}250 \text { 年再現期間 } \\
(50 \text { 年超過確率 } 0.18)\end{array}$} & \multicolumn{2}{|c|}{$\begin{array}{c}75 \text { 年再現期間 } \\
(50 \text { 年超過確率 } 0.49)\end{array}$} \\
\cline { 2 - 5 } & \multicolumn{2}{|c|}{$V \geqq v_{250}$} & \multicolumn{2}{|c|}{$V \geqq v_{75}$} \\
\hline 地点 & $V$ (kine) & $\begin{array}{c}\text { 平均継続時間 } \\
(\mathrm{sec})\end{array}$ & $V(\mathrm{kine})$ & $\begin{array}{c}\text { 平均継続時間 } \\
(\mathrm{sec})\end{array}$ \\
\hline MYGH06 & 34.7 & 16.9 & 21.4 & 19.8 \\
\hline TKY007 & 51.3 & 32 & 30.5 & 40.3 \\
\hline SZO014 & 194 & 1.46 & 111 & 3.29 \\
\hline AIC015 & 149 & 14.2 & 91 & 15.3 \\
\hline OSK005 & 109 & 43.3 & 65.1 & 45.5 \\
\hline FKOH01 & 26.4 & 46.9 & 14.4 & 61.3 \\
\hline
\end{tabular}

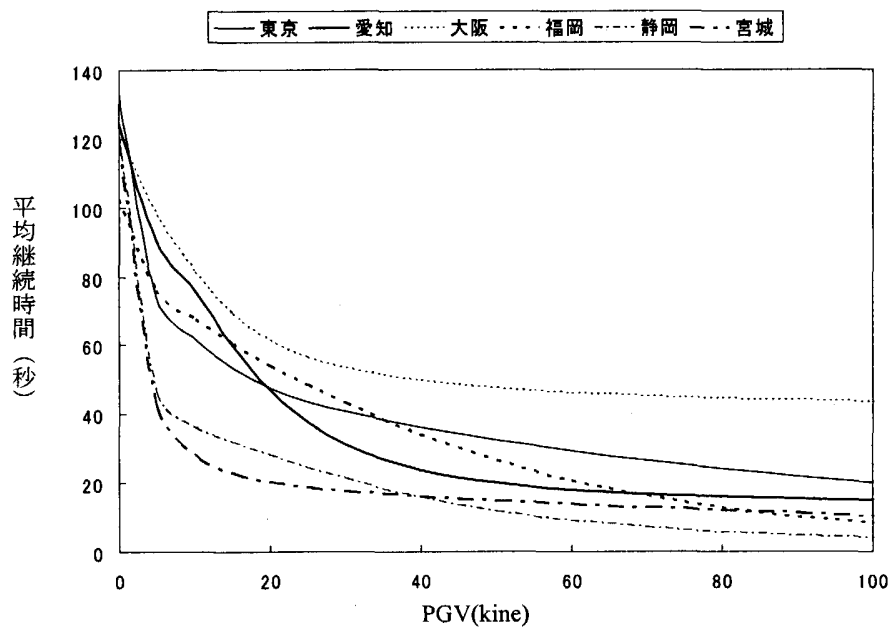

図 8.PGVに対する条件付平均継続時間

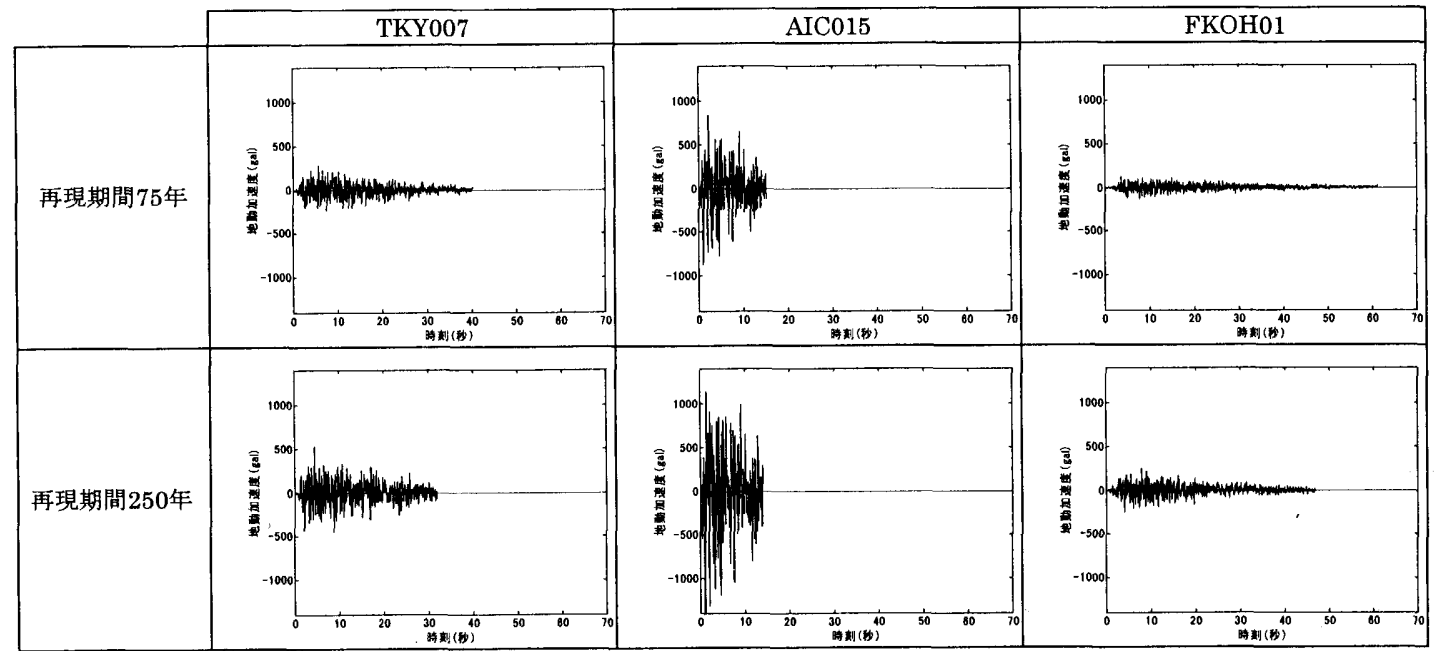

図 9.作成された模擬地震動

強度の再現期間を決定すると同時に地域特性を考慮した継続時間の 分布を算出できる。図 7 の継続時間の条件付確率密度関数から 250 年再現期間、75 年再現期間について平均継続時間を式（17）より計 算した。その結果および $V$ の值を表 5 に示す。このように地震動強 度の再現期間が与えられた時の継続時間の分布を定めることができ、 それから代表值を決定することができる。
さらにVを変化させた平均継続時間を図8に示す。これからわかる ことは全ての地域について $V$ が大きくなると継続時間が短くなり、 直下型の地震動の影響が大きくなることがわかる。 小さい地震動強度が指定された場合（短い再現期間）には遠い地震が 多く含まれるために、継続時間は長いものが代表值となり、逆に大き い地震動強度の場合には、敷地に対して近距離の地震が支配的となる 
ため、短い継続時閒が選定される。

\section{3. 模擬地震動作成}

本研究で評価された同時確率密度関数により、Vの指定超過確率での 継続時間の確率密度を計算できる。従来の $V$ だけで震源を特定して いた手法より、本研究は経時特性のうち継続時間を考慮に入れて震源 を予測できるという利点があるといえる。周波数の特定は今後の課題 とし、本研究では荷重指針 ${ }^{17)}$ に用いられている速度応答スペクトル を用いて模擬地震動を作成した。作成された模擬地震動を図 9 に示す。 これらから地震動の振幅だけでなく継続時間も評価地点に適合した 值となっていることがわかる。

\section{6. まとめ}

本研究では、従来おこなわれている単一のハザード指標を用いた確率 論的地震八ザード解析だけでは、将来生じる地震動の性質を表現する には十分とはいえないことから、複数のハザード指標を同時に評価す る地震ハザード解析について検討を行った。多地点強震観測記録を用 いて地震動強さと経時特性の指標のばらつきや相関を評価し、これを 用いて地震動強さと経時特性を同時に評価した確率論的地震八ザー ド解析の手法を提案して、実際のサイトに適用した。これによって、 評価対象地点において将来生じうる地震動の性質を、確率論的により 詳細に表現できることを示した。

得られた同時確率密度関数の忘用例として、地動最大速度に関して 設計用再現期間が与えられた場合に、継続時間の条件付確率密度関数 より、その代表值を選び時刻歴波形を作成する方法を紹介し、日本の いくつかの都市に適用した。

今後は、周波数特性の地域性を考虑に入れて解析を実施する予定で ある。

\section{謝辞}

K-net, KiK-net より貴重な記録を利用させて頂いた。ここに独立行政 法人防災科学技術研究所に深謝するとともに、本研究のプログラム作 成において協力を得た下村哲人氏（2003年修士卒）に記して謝意を表 する。

\section{参考献}

1）大䗁順彦:新・地震動のスペクトル解析入門，鹿島出版, 1994

2) Hirao, K., T. Sawada, Y. Nariyuki and S. Sasada: The effect of frequency characteristics and duration of input earthquake motion on the energy response of structures, Structural Eng./

Earthquake Eng. Vol. 4, No. 2, pp. 381s-390s, 1987

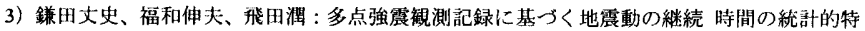
性と推定式、日本建築学会学術講演梗概集、B-2、構造 II、pp.195-196、2003.9

4）後藤尚男, 杉戸真太, 亀田弘行, 斉藤宏, 大滝健: 工学基盤における地震動予测モデル, 京都大学防災研究所年報 第 27 号 B-2, 1984

5) 基準地震動の策定方法の見值しに関する調查報告書, 原子力発電酎震設計特別調查委貝会 調查報告書, 1994

6）大崎順彦: 原子力発電所設計用の基淮地震動評洒に関するガイドライン, ORI 研究報告 84-01, 1984

7）翠川三郎，大竹雄: 地震動強さの距離減衰式に見られるバラツキに関する基礎的分析，日
本地震工学会論文集, 第 3 卷, 第 1 号, PP. 59-70, 2003.

8）松岡昌志, 翠川三郎: 国土数值情報とサイスミックマイクロソーニング, 日本建築学会第 22 回地盤震動シンボジウム, pp.23-34, 1994.

9）亀田,弘行 石川裕: ハザード適合マグニチュード・震央距離による地震危険度解析の拡張, 土木学会論文集 第 392 号, pp.395-402, 1988

10）高田毅士, 越智紗香,神田順: 確率論的想定地震の選定方法に関する基䃈的考察 日本建 築学会構造系論文集, PP. 563, 53-59, 2003

11）太田外気晴，丹羽正徳，安藤治彦，有子山直樹：模擬地震波作成のための地震動の最大速 度と最大加速度の関㐿ならびに主要動部の継続時間, 鹿息建設技術研究所年報, 第 24 号, 1976

12）川岛一彦，相沢興，高橋一之：強震記録の重回㷌分析に基づく地䢅動加速度の継続時間 の推定法，土木技術資料，27-4，pp.187-193，1985

13）沢田勉，永江正広，平尾潔：位相差分に上る地震動継続時間の定義とその統計解析，土木 学会論文集 第 368 号 $/ \mathrm{I}-5$, pp.373-382, 1986

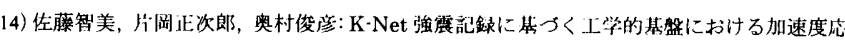
答スペクトルと経時特性の推定式の検討，第 11 问日本地祳L学シンポジウム, pp.615-620, 2002 .

15) Cornell C A.; Engineering Seismic Risk Analysis. Bull Seism Soc Am, 1968, 58(5) pp.1583 1606

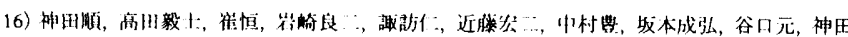

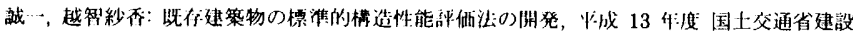
技術開発費補助金研究成果報告霄, 2002.

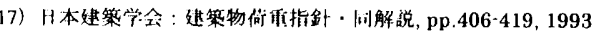

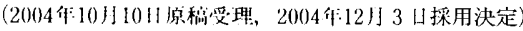

